\title{
Agrobacterium-Mediated Transformation of Three Freshwater Microalgal Strains
}

\author{
MARY SANITHA, SUDHAKAR RADHA, ANWAR ALIYA FATIMA, SELVARAJU GAYATHRI DEVI \\ and MOHANDASS RAMYA*
} Department of Genetic Engineering, School of Bioengineering, SRM University, Kattankulathur,
Kancheepuram District, Tamil Nadu, India

Submitted 12 May 2014, revised 6 August 2014, accepted 10 August 2014

\begin{abstract}
Microalgal transformation has gained interest in recent years. Agrobacterium-mediated transformation remains as the most efficient method for the development of transgenic plants and microalgae due to its wide host range, inexpensive procedure and transfer of large segments of DNA. In the present study, three different microalgal species were isolated from freshwater environment and identified based on the morphological characteristics and ITS-2 region amplification. Agrobacterium-mediated transformation was successful for the isolates Chlorella sp., Ankistrodesmus sp and Scenedesmus bajacalifornicus. Gene integration and expression was confirmed by PCR amplification of hptII and GUS histochemical assay. A. tumifaciens contamination was checked by amplification of $n p t$ II gene (kanamycin resistant) which lies outside the T-border. Based on GUS assay, transformation efficiencies were found to be $12.25 \%$ for Chlorella sp. $2.96 \%$ for Scenedesmus bajacalifornicus and 3.5\% for Ankistrodesmus sp.
\end{abstract}

Ke y words: Agrobacterium tumefaciens, GUS intron, LBA4404, transgenic microalgae

\section{Introduction}

Microalgae have emerged as an important system for various biotechnological applications such as production of biofuel, vitamins, carotenoids, enzymes, pharmaceuticals and recombinant proteins (Barrow and Shahidi, 2008; Liam and Philip, 2010; Potvin and Zhang, 2010). Freshwater microalgal species are advantageous for to its high biomass and lipid production over marine and waste water microalgae (Mata et al., 2010). Freshwater species like Chlorella vulgaris, Haematococcus pluvialis, Dunaliella salina and Spirulina maxima (cyanobacteria) are used as nutritional supplements in humans and as feed additives in animals (Pulz and Gross, 2004).

In the current scenario genetic improvement of microalgae is required to enhance the microalgal potential for biotechnological applications. For the purpose of genetic improvement suitable transformation methods are required. Algae can be genetically transformed by using Agrobacterium (Rajam and Kumar, 2006), by direct transformation using glass beads or silicon carbide whiskers (Kindle, 1990; Wang et al., 1995), by particle bombardment (Koop et al., 2007) and by electroporation (Ladygin, 2003; Niu et al., 2011).
In recent years considerable progress has been made in Agrobacterium-mediated transfer of gene to microalgal species. Agrobacterium mediated transformation has significant advantage over other methods, in producing higher transformation efficiency, stable integration of DNA fragments reducing the frequency of rearrangements, introduction of fewer copies of the transgene into the host genome. Agrobacterium tumefaciens can be used to transfer large sized genes (Hallmann, 2007; Kiliana et al., 2011).

Agrobacterium-mediated genetic transformation was successful in a variety of freshwater algal strains such as Chlamydomonas reinhardtii (Kumar et al., 2004), Haematococcus pluvialis (Kathiresan and Sarada, 2009), Chlorella vulgaris (Cha et al., 2012) and marine microalgal strains Parachlorella kessleri (Rathod et al., 2013), Schizochytrium (Cheng et al., 2012), Nannochloropsis sp. (Cha et al., 2011) and Dunaliella bardawil (Anila et al., 2011).

Genetic transformation using Agrobacterium has been successful only for a few species amongst the freshwater microalgal strains (Kumar et al., 2004; Cha et al., 2012; Kathiresan and Sarada, 2009). Fresh water microalgae being economically important, methodology development for genetic transformation studies will be

\footnotetext{
* Corresponding author: M. Ramya, Department of Genetic Engineering, School of Bioengineering, SRM University, Kattankulathur, Kancheepuram District, Tamil Nadu, India; e-mail: ramya.mohandass@gmail.com
} 
useful for product improvement or value addition. In this study, fresh water microalgal isolates Chlorella sp., Ankistrodesmus sp. and Scenedesmus bajacalifornicus were genetically transformed using Agrobacterium tumefaciens harboring vector pCAMBIA 1301. Stable gene integration was studied using the GUS ( $\beta$-glucuronidase) and hygromycin markers in transformed algal species.

\section{Experimental}

\section{Materials and Methods}

Medium and antibiotics used. BG 11 medium ( $\mathrm{pH} 7 \pm 0.05$ ) was used for culturing of all the algal strains. The macronutrients of the medium consists of $\mathrm{NaNO}_{3}\left(1.5 \mathrm{~g} \mathrm{l}^{-1}\right) ; \mathrm{K}_{2} \mathrm{HPO}_{4}\left(40 \mathrm{mg} \mathrm{l}^{-1}\right) ; \mathrm{MgSO}_{4} \cdot 7 \mathrm{H}_{2} \mathrm{O}$ $\left(75 \mathrm{mgl}^{-1}\right) ; \mathrm{CaCl}_{2} \cdot \mathrm{H}_{2} \mathrm{O}\left(36 \mathrm{mg} \mathrm{l}^{-1}\right) ; \mathrm{Na}_{2} \mathrm{CO}_{3}\left(20 \mathrm{mg} \mathrm{l}^{-1}\right)$; $\mathrm{Na}_{2}$ EDTA $\left(1 \mathrm{mg} \mathrm{l}^{-1}\right)$; Citric acid $\left(6 \mathrm{mg} \mathrm{l}^{-1}\right)$ and $\mathrm{C}_{6} \mathrm{H}_{8} \mathrm{FeNO}_{7}\left(6 \mathrm{mg} \mathrm{l}^{-1}\right)$ and the micronutrients $\left(\mathrm{mg} \mathrm{l}^{-1}\right)$ were $\mathrm{H}_{3} \mathrm{BO}_{3}$ (28.6); $\mathrm{MnCl}_{2}(18) ; \mathrm{ZnSO}_{4}$ (2.2); $\mathrm{CuSO}_{4}$ (7); $\mathrm{Co}\left(\mathrm{NO}_{3}\right)_{2}$ (4.9) and $\mathrm{Na}_{2} \mathrm{MoO}_{4}$ (39) (Stanier et al., 1971). A binary vector PCAMBIA 1301, which has a bacterial hpt and a GUS intron each under the CaMV35S promoter was used in this study (Rathod et al., 2013). The vector PCAMBIA 1301 was maintained in Agrobacterium tumefaciens LBA4404 which was gifted by MSSRF (Chennai, India). Kanamycin $\left(50 \mu \mathrm{g} \mathrm{ml}^{-1}\right)$ was used as the bacterial selection and hygromycin $\left(25 \mu \mathrm{g} \mathrm{ml}^{-1}\right)$ was the algal selection marker.

Isolation and identification of microalgal strains. Water samples were collected from various freshwater lakes and ponds from different parts of Tamil Nadu, India. Water samples $(10 \mathrm{ml})$ were inoculated into $100 \mathrm{ml}$ of sterilized BG-11 broth and incubated at $25 \pm 1^{\circ} \mathrm{C}$ temperature, under light intensity $100 \mu \mathrm{mol}$ photon $\mathrm{m}^{-2} \mathrm{~s}^{-1}$ with 16:8 h light and dark cycles. The algal samples were subjected for purification using serial dilution followed by plating in BG11 medium. The individual algal colonies were inoculated into liquid BG-11 media and incubated for further growth. The morphology of the isolates was checked under light microscope (Hund Wizard, Germany). Chlamydomonas reinhardtii (CC-124) obtained from Chlamydomonas Genetics Centre, Duke University, Minnesota was used as a positive control (Kumar et al., 2004). All the strains were maintained on solid and liquid BG-11 ( $\mathrm{pH} 7 \pm 0.05)$ in plant growth chamber under the above growth conditions.

Molecular identification of microalgae. Colony PCR protocol was followed for all the species as per previous study (Radha et al., 2013). The internal transcribed spacer (ITS-2) region of each isolate was amplified using universal primer (Hall etal., 2010). The primer sequence for ITS- 2 region includes forward 5'ATGCGATACTTGGTGTGAAT-3' and reverse 5'-GACGCTTCTCCAGACTACAAT-3'. The PCR reaction components for $50 \mu \mathrm{l}$ reaction mix includes $1 \mu \mathrm{l}$ of DNA template, $1 \mathrm{U}$ of Taq DNA polymerase (Bangalore Genei, India) , $5 \mu \mathrm{l}$ of 10X PCR buffer, $1 \mu \mathrm{dNTP}$ mix ( $10 \mathrm{mM}$ each nucleotide), $1 \mu \mathrm{l}$ of primer (5 pico moles of each, forward and reverse) (Bioserve, India). The conditions for PCR used were initial denaturation at $95^{\circ} \mathrm{C}$ for $5 \mathrm{~min}$, annealing at $55^{\circ} \mathrm{C}$ for 30 seconds, extension at $72^{\circ} \mathrm{C}$ for $1 \mathrm{~min}$ for 35 cycles of ITS- 2 region. The PCR reaction was carried out using Thermal Cycler (Applied Biosystems, USA). The PCR products were examined on $1 \%(\mathrm{w} / \mathrm{v})$ agarose gel with the $100 \mathrm{bp}$ DNA ladder. The amplified products were purified using EZ-10 column purification kit (Biobasic Inc., USA) and subjected to sequencing using Automated DNA Sequencer AB1 3130 XL (Genetic Analyser, Applied Biosystems, USA). The obtained sequence was analyzed using BLASTN (http://blast.ncbi.nlm.nih.gov/Blast.cgi) and submitted to GenBank. The obtained sequences were aligned using CLUSTAL W and subjected to phylogenetic tree construction using MEGA4 software (Tamura and Dudley, 2007). The unrelated species Uronema heteromarinum (JN885101.1) has been chosen as an out group to build a phylogenetic tree.

Sensitivity of microalgal strains towards antibiotic hygromycin. The algal strains were serially diluted and plated $(100 \mu \mathrm{l})$ on BG-11 plates containing the antibiotic hygromycin $\left(25 \mu \mathrm{g} \mathrm{ml}^{-1}\right)$ and the plates were incubated at $25 \pm 1^{\circ} \mathrm{C}$ for a week to observe the growth (Rathod et al., 2013).

Transformation of microalgal strains by Agrobacterium co-cultivation. Transformation was done by co-cultivating the microalgal strains with $A$. tumefaciens LBA4404 (Kumar et al., 2004). The algal cultures were plated onto the solid BG-11 medium and were incubated in light to allow a lawn of cells to be formed. A.tumefaciens LBA4404 culture in liquid

Table I

Sensitivity of isolated freshwater microalgal strains with Hygromycin $\left(25 \mu \mathrm{g} \mathrm{ml}^{-1}\right)$

\begin{tabular}{|c|l|c|}
\hline No & \multicolumn{1}{|c|}{$\begin{array}{c}\text { Microalgal strains used } \\
\text { in the study }\end{array}$} & $\begin{array}{c}\text { Hygromycin } \\
\left(25 \mu \mathrm{ml}^{-1}\right)\end{array}$ \\
\hline 1 & C. proboscideum. SRM01 & Sensitive \\
\hline 2 & Chlorella sp. SRM02 & Sensitive \\
\hline 3 & Desmodesmus sp. SRM03 & Sensitive \\
\hline 4 & Scenedesmus sp. SRM04 & Sensitive \\
\hline 5 & S. obliquus SRM05 & Sensitive \\
\hline 6 & C. sorokiniana SRM06 & Resistant \\
\hline 7 & Micractinium sp. SRM07 & Sensitive \\
\hline 8 & S. bajacalifornicus SRM08 & Sensitive \\
\hline 9 & Ankistrodesmus sp. SRM 09 & Sensitive \\
\hline
\end{tabular}


YEP (A600-0.5 OD) was plated onto the thin-layer of algal cultures grown on BG-11 plate. Following cocultivation for $48 \mathrm{~h}$, cells were harvested, washed twice with liquid BG-11 medium containing $500 \mu \mathrm{g} \mathrm{m}^{-1}$ cefotaxime by centrifugation at $10,000 \mathrm{rpm}$ for $2 \mathrm{~min}$, resuspended in liquid BG-11 media and plated on to solid BG-11 containing $25 \mu \mathrm{g} \mathrm{m}^{-1}$ hygromycin and $500 \mathrm{\mu g} \mathrm{ml}^{-1}$ cefotaxime. Transformed colonies appeared in a week; and transformed individual colonies were maintained on the same medium containing hygromycin $\left(25 \mu \mathrm{g} \mathrm{ml}^{-1}\right)$ and cefotaxime $\left(500 \mu \mathrm{g} \mathrm{ml}^{-1}\right)$.

Selection of transformed algal colonies by colony PCR. After co-cultivation, transformed colonies were selected and inoculated into BG-11 broth containing hygromycin $\left(25 \mu \mathrm{g} \mathrm{ml}^{-1}\right)$. Further these colonies were used for colony PCR using primers for GUS intron (190 bp), CaMV35S promoter ( $800 \mathrm{bp}$ ) and $n p t$ II gene $(800 \mathrm{bp})$. Amplification of ITS- 2 region was used as positive control. The following primer sequences were used in the study. GUS intron F 5'AGTAAA TTTCTAG TTTTTCTCC3' GUS intron R 5'TGTAA CTATCATCATCATC3', CaMV35SF 5'GTCGACGCTT GCCAACATGGTGGA3' CaMV35SR 5'TCTAGAAGA GATAGATTTGTAGAGAAG3', ITS F 5'AGGAGAAGTCGTAACAAGGT 3', ITS R 5'TCCTCCGCTTATTGATATGC3' and npt II F 5'TCAGAAGAACTCGTCAAGAAG 3', npt II R 5'ATGGGGATTGAACAAGATG 3' (Subramanyam et al., 2011). The presence of Agrobacterium tumefaciens contamination was checked using PCR amplification of $n p t I I$ gene fragment $(800 \mathrm{bp})$. This gene confers resistance to kanamycin. Amplification of $n p t I I$ in plasmid pCAMBIA 1301 was used as positive control.

Histochemical assay. Transformed algal cultures ( $1 \mathrm{ml}$ of each) were harvested by centrifugation at $6500 \mathrm{rpm}$ and washed with sterile distilled water and $0.1 \mathrm{M} \mathrm{Na}_{3} \mathrm{PO}_{4}$ buffer ( $\mathrm{pH} 7.0$ ). The algal cell pellet was resuspended in $500 \mu \mathrm{l}$ GUS histochemical assay buffer and incubated overnight at $37^{\circ} \mathrm{C}$. Following GUS assay, chlorophyll was cleared by incubation for $1-2 \mathrm{~h}$ in $70 \%$ (v/v) ethanol and cells were resuspended in 40\% (v/v) glycerol (Cha et al., 2011). Cells were counted in a haemocytometer chamber under a light microscope (Hund wizard, Germany). Cells spotted as blue were recorded as transformed. Transformation efficiency was calculated as the number of GUS positive cells/total number of cells counted $(\times 100 \%)$. All the experiments were repeated thrice and the mean value was taken for the analysis.

\section{Results and Discussion}

Isolation of microalgae. Microalgae are present in diverse environments such as aquatic, terrestrial, freshwater, brackish water, seawater and wastewater (Richmond, 2004). It is estimated that more than 100,000 species exist (Lin et al., 2011). In this study, three different microalgal species were isolated from freshwater samples and morphological identification of the isolates was carried out using microscopic observation (Hund wizard, Germany). Based on the morphological features like cell shape and size the isolated strains were identified as Scenedesmus (4 cells are joined together and lying parallel to each other), Ankistrodesmus (cells are curved with tapered ends, size is about $20-30 \mu \mathrm{m}$ in diameter) and Chlorella (spherical in shape, size $2-20 \mu \mathrm{m}$ in diameter) (Fig. 1).

Molecular identification of microalgal strains. Morphologically different microalgal colonies were obtained upon serial dilution and plating. These colonies were subjected to molecular identification using ITS- 2 as a marker. ITS- 2 amplified products of the isolated microalgal strains were gel purified and sequenced. The sequences were analyzed using BLAST (http://blast.ncbi.nlm.nih.gov/Blast.cgi). The Genbank

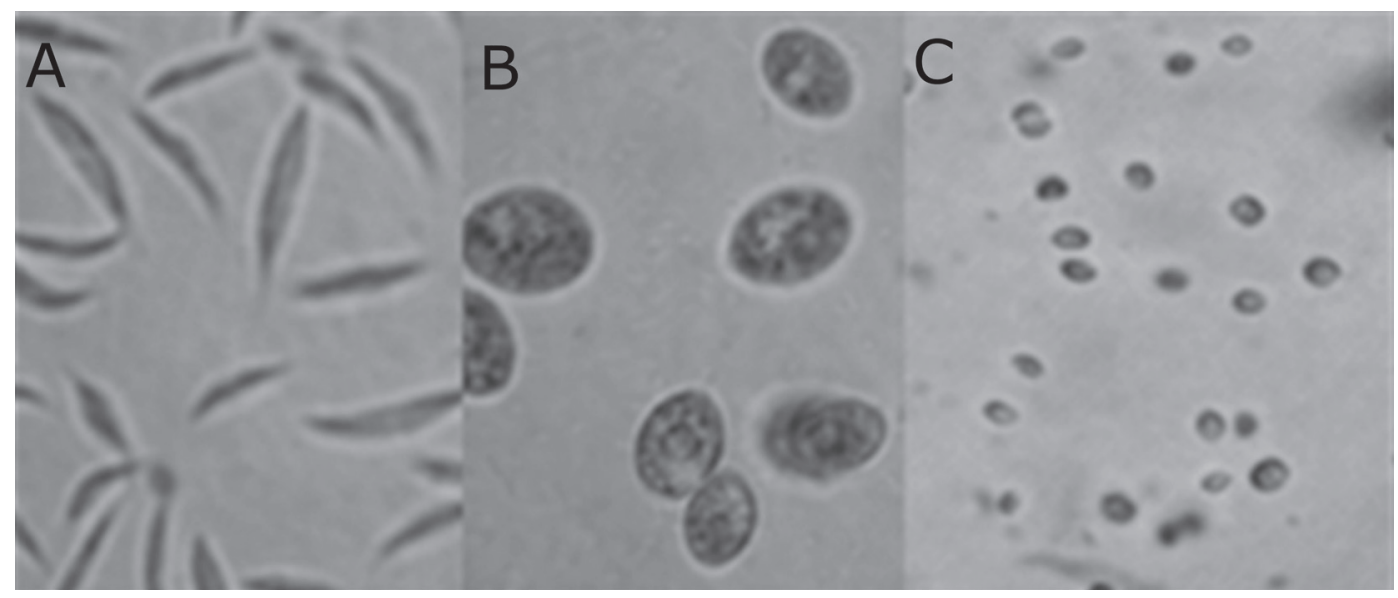

Fig.1. Microscopic (40X) observation of three freshwater isolates (a) Ankistrodesmus sp. (b) S.bajacalifornicus and (c) Chlorella sp. 


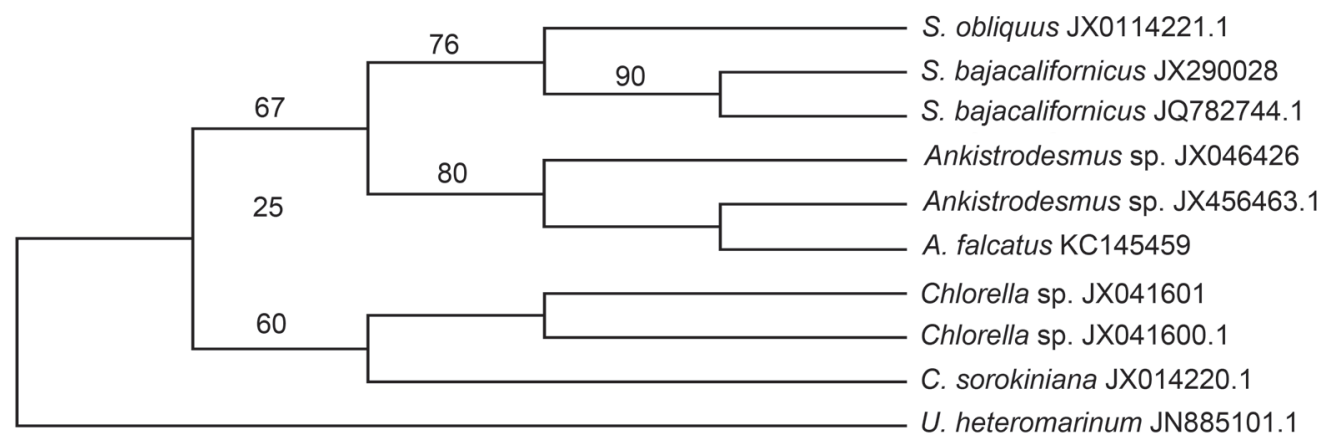

Fig. 2. Phylogenetic analysis results of Chlorella sp., S. bajacalifornicus and Ankistrodesmus sp.

accession number and percentage similarity values of the isolates were as follows: Chlorella sp. JX041601 (100\%), Scenedesmus bajacalifornicus JQ782744 (95\%) and Ankistrodesmus sp. JX456463 (88\%).

Phylogenetic tree is used to determine the evolutionary relationship between various species (Penny et al., 1992). Molecular based phylogenetic techniques have been employed as an important tool in algal taxonomic studies (Brodie and Lewis, 2007). ITS-2 sequence has been widely used in species level identification of green algae (O'Kelly et al., 2010). In a study carried out by Ratha et al., (2012), phylogenetic tree was constructed using ITS-2 molecular marker for microalgal biodiversity analysis. The percentage similarity values were obtained for all the isolated species after pair wise alignment of the ITS- 2 sequence. Phylogentic tree shows that, the isolated species were closely related to the genus of Scenedesmus, Chlorella and Ankistrodesmus sp (Fig. 2).

Antibiotic sensitivity of microalgal strains. Microalgal strains isolated from fresh water samples were tested for sensitivity against hygromycin before transformation analysis. When the algal strains were plated on BG-11 plates containing hygromycin $\left(25 \mu \mathrm{g} \mathrm{ml}^{-1}\right)$, no growth was observed for the strains Ankistrodesmus sp. Chlorella sp and S. bajacalifornicus at the end of 12 days. This shows that these strains were sensitive to hygromycin; hence they were used for further transformation study with pCAMBIA 1301 which has hygromycin as selection marker.

Transformation of microalgal strains. Agrobacterium tumifaciens containing plasmid pCAMBIA
1301 was co-cultivated with algal strains and a mat of cells were formed. After $72 \mathrm{~h}$, the cells were harvested, serially diluted and plated on solid BG-11 containing hygromycin $\left(25 \mu \mathrm{g} \mathrm{ml}^{-1}\right)$ and cefotaxime $\left(500 \mu \mathrm{g} \mathrm{ml}^{-1}\right)$. After 9 days, colonies were observed on the plate. Cefotaxime inhibits bacterial cell wall synthesis and thereby prevents the growth of the bacteria (Da silva et al., 2001). After co-cultivation, growth was observed for all the three isolates Ankistrodesmus sp., Chlorella sp. and S. bajacalifornicus. Among the isolated species Chlorella sp. were studied earlier for Agrobacteriummediated transformation (Cha et al., 2012). So far, there are no reports available for the other two strains Ankistrodesmus sp. and S. bajacalifornicus used in this study.

Selection of transformed colonies. CaMV35S promoter drives the reporter genes UidA ( $\beta$-glucuronidaseGUS) and selection marker $h p t I I$ (Hygromycin phosphortransferase). Amplification for GUS intron and CaMV35S promoter regions in the transformed algal species indicates that the plasmid had been integrated into the microalgal strains through A.tumifaciens. The expected sizes of the amplified GUS intron and CaMV35S promoter regions are 190 and $800 \mathrm{bp}$, respectively. The predicted PCR products were obtained in Ankistrodesmus sp., Chlorella sp., S. bajacalifornicus and positive control C. reinhardtii CC-124 after transformation (data not shown).

Agrobacterium tumifaciens contamination in the transformed colonies was analyzed by PCR amplification of the npt II gene fragment. This kanamycin resistace gene (nptII) is commonly used as a bacte-

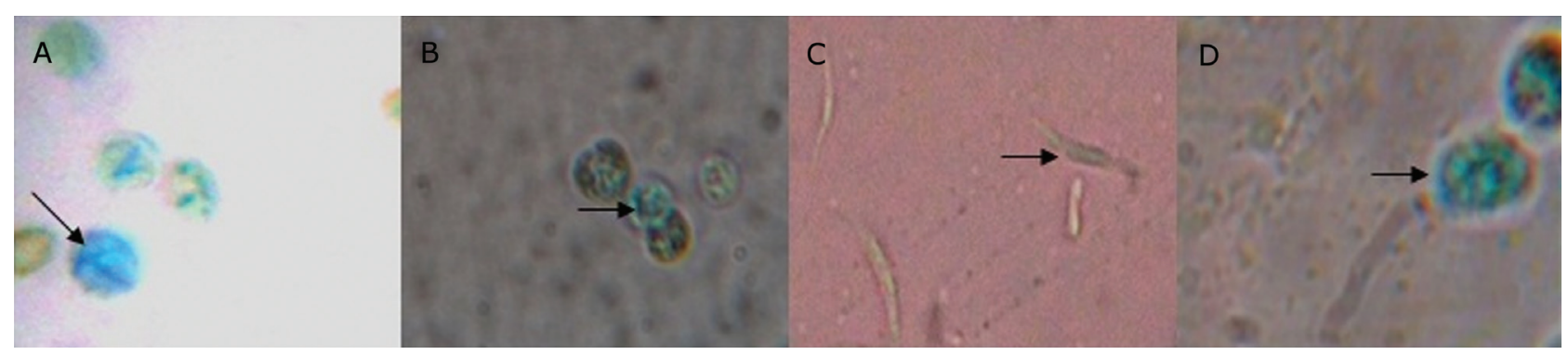

Fig. 3. Microscopic observation (100X) of GUS-positive transformed cells. Arrow indicates the blue coloured cell demonstrating the transfer of pCAMBIA into (a) S. bajacalifornicus (b) Chlorella sp. (c) Ankistrodesmus sp., and (d) C. reinhardtii CC-124 
rial selection marker. Therefore, if there was any bacterial contamination, amplification would have been obtained at $800 \mathrm{bp}$. No amplification for $n p t$ II gene for all transformed microalgal strains was detected, which indicates that there is no A. tumifaciens contamination in the transformed colonies.

GUS histochemical assay. GUS histochemical assay was performed to check the expression of GUS in transformed microalgal cells. This assay was performed after hygromycin screening for all the isolated species. GUS gene ( $\beta$-glucuronidase) commonly utilized as a "marker gene" for plant genetic transformation. $\beta$-glucuronidase in the cells reacts with the substrate (X-gluc) 5-bromo-4-chloro-3-indolyl glucouronide. This reaction makes the cell to appear in blue colour (Jefferson et al., 1987). Figure 3 (a, b, c and d), shows the microscopic view of the transformed S. bajacalifornicus, Chlorella sp., Ankistrodesmus sp. and C. reinhardtii CC-124. The blue coloured cells were recorded as transformed cells whereas the non transformed cells showed no blue color. Based on the GUS assay, the transformation efficiency of three microalgal species were found to be, Chlorella sp. (12.25\%), S. bajacalifornicus (2.96\%) and Ankistrodesmus sp. (3.5\%).

In conclusion, Agrobacterium-mediated gene transfer is a commonly used technique for plants and it is a less expensive and easy method. Recent studies suggested that, Agrobacterium-mediated gene transfer is possible for microalgal species. The current study will provide a platform for further development in biofuel production and other applications of microalgae. In the present study, three freshwater microalgal species Ankistrodesmus sp., Chlorella sp. and S. bajacalifornicus were isolated from freshwater samples and subjected for A.tumifaciens mediated transformation, using PCAMBIA 1301. The plasmid integration was detected by PCR amplification for GUS intron gene and CaMV35S promoter region. GUS histochemical assay was performed to check the expression of GUS gene in transformed microalgal strains to determine the transformation efficiencies. This technique has to be further exploited for the genetic improvement of many other microalgal species.

\section{Acknowledgments}

We greatly acknowledge SRM University for providing fund and infrastructure facility for this project. We would like to thank Mr. Rex Arunraj for providing pCAMBIA 1301 vector.

\section{Literature}

Anila N., A. Chandrashekhar, G.A. Ravishankar and R. Sarada. 2011. Establishment of Agrobacterium tumefaciens mediated genetic transformation in Dunaliella bardawil. Eur. J. Phycol. 1: 36-44.
Barrow C. and F. Shahidi. 2008. Marine nutraceuticals and functional foods. CRC Press, Taylor \& Francis Group. pp. 247-258. Brodie J. and J. Lewis. 2007. Untravelling the Algae: the Past, present and future of algal systematics. CRC press, Bocaration, USA.

Cha T.S., C.F. Chen, W. Yee, A. Aziz and S.H. Loh. 2011. Cinnamic acid, coumarin and vanillin:alternative phenolic compounds for efficient Agrobacterium-mediated transformation of the unicellular green alga, Nannochloropsis sp. J. Microbiol. Meth. 84: 430-434. Cha T.S., W. Yee and A. Aziz. 2012. Assessment of factors affecting Agrobacterium-mediated genetic transformation of the unicellular green alga, Chlorella vulgaris. World J. Microbiol. Biotechnol. 28: 1771-1779.

Cheng R., R. Ma, K. Li, H. Rong, X. Lin, Z. Wang, S. Yang and Y. Ma. 2012. Agrobacterium tumefaciens mediated transformation of marine microalgae Schizochytrium. Microbiol. Res. 167: 179-186. da Silva J.A.T. and S. Fukai. 2001. The impact of carbenicillin, cefotaxime and vancomycinon chrysanthemum and tobacco TCL morphogenesis and Agrobacterium growth. J. Appl. Hort. 3(1): 3-12. Hall J.D., K. Fucikova, C. Lo, L.A. Lewis and K.G. Karol. 2010. An assessment of proposed DNA barcodes in freshwater green algae. Cryptogam Algol. 31:529-555.

Hallmann A. 2007. Algal transgenics and biotechnology. Transgenic Plant J. 1(1): 81-98.

Jefferson R.A. 1987. Assaying chimeric genes in plants: the GUS gene fusion system. Plant Mol. Biol. Rep. 5: 387-405.

Kathiresan S. and R. Sarada. 2009. Towards genetic improvement of commercially important microalga Haematococcus pluvialis for biotech applications. J. Appl. Phycol. 21: 553-558.

Kiliana O., C.S.E. Benemanna, K.K. Niyogi and B. Vicka. 2011. High-efficiency homologous recombination in the oil-producing alga Nannochloropsis sp. Proc. Natl. Acad. Sci. USA. 108(52): 21265-21269.

Kindle K.L. 1990. High-frequency nuclear transformation of Chlamydomonas reinhardtii. Proc. Natl. Acad. Sci. USA. 87: 1228-1232. Koop H.U., S. Herz and T. Golds. 2007. The genetic transformation of plastids. Pp: 457-510, In: Bock Ralph (ed) Cell and molecular biology of plastids. Topics in current genetics. Berlin: Springer.

Kumar S.V., R.W. Misquitta, V.S. Reddy, B.J. Rao and M.V. Rajam. 2004. Genetic transformation of the green alga-Chlamydomonas reinhardtii by Agrobacterium tumefaciens. Plant Sci.166: 731-738.

Ladygin V.G. 2003. The transformation of the unicellular alga Chlamydomonas reinhardtii by electroporation. Microbiol. 72: 585-591.

Liam B. and O. Philip. 2010. Biofuels from microalgae-A review of technologies for production processing, and extraction of biofuels and co-products, Renew. Sust. Energ. Rev. 14: 557-577.

Lin L., C. Zhou, V. Saritporn, X. Shen and M. Dong. 2011. Opportunities and challenges for biodiesel fuel. Appl. Ener. 88: 1020-31.

Mata T.M., A.A. Martins and N.S. Caetano. 2010. Microalgae for biodiesel production and other applications: a review. Renew. Sust. Energ. Rev. 14: 217-232.

Niu Y.F., M.H. Zhang, W.H. Xie, J.N. Li, Y.F. Gao, W.D. Yang, J.S. Liu and H.Y. Li. 2011. A new inducible expression system in a transformed green alga Chlorella vulgaris. Genet. Mol. Res. 10 (4): 3427-3434.

O'kelly C.J., A. Kurihara, T.C. Shipley and A.R. Sherwood. 2010. Molecular assessment of Ulva spp. (Ulvophyceae, Chlorophyta) in the Hawaiian Islands. J. Phycol. 6: 728-735.

Penny D., M.D. Hendy and M.A. Steel. 1992. Progress with methods for constructing evolutionary trees. Trends Ecol. Evol. 7: 73-79. Potvin G. and Z. Zhang. 2010. Strategies for high-level recombinant protein expression in transgenic microalgae: a review. Biotechnol. Adv. 28: 910-918.

Pulz O. and W. Gross. 2004. Valuable products from biotechnology of microalgae. Appl Microbiol. and Biotechnol. 65(6): 635-48. 
Ratha S.K., R. Prasanna, V. Gupta, D.W. Dhar and A.K. Saxena. 2012. Bio-prospecting and indexing the microalgal diversity of different ecological habitats of India. World J. Microbiol. Biotechnol. 28: 1657-1667.

Radha S., A. Aliya Fathima, S. Iyappan and M. Ramya. 2013. Direct colony PCR for rapid identification of varied microalgae from freshwater environment. J. Appl. Phycol. 25: 609-613.

Rajam M.V. and S.V Kumar. 2006. Green alga (Chlamydomonas reinhardtii). Methods in Mol. Biol. 344: 421-434.

Rathod J.P., G. Prakash, G. Pandit and A.M. Lali. 2013. Agrobacterium-mediated transformation of promising oil-bearing marine algae Parachlorella kessleri. Photosynth. Res. 118 (1-2): 141-146.

Richmond A. 2004. Handbook of microalgal culture: biotechnology and applied phycology. Blackwell Science Ltd.
Stanier R.Y., M.M. Kunisawa and G. Cohen-Bazire. 1971. Purification and properties of unicellular blue-green algae (order Chroococcales). Bact. Rers. 35: 171-201.

Subramanyam K. K. Subramanyam, K.V. Sailaja, M. Srinivasulu and K. Lakshmidevi. 2011. Highly efficient Agrobacterium-mediated transformation of banana cv. Rasthali (AAB) via sonication and vacuum infiltration. Plant Cell Rep. 30(3): 425-36.

Tamura K. and J. Dudley. 2007. MEGA4: Molecular evolutionary genetics analysis (MEGA) software version 4.0. Mol. Biol. Evol. 24: 1596-99.

Wang K., P. Drayton, B. Frame, J. Dunwell and J. Thompson. 1995. Whisker-mediated plant transformation - an alternative technology. In Vitro Cell Dev. Biol. Plant 31: 101-104. 